\title{
Outline of Mimesis, Honor and Dignity in Modern Sport: A Commentary
}

Authors' contribution:

A) conception and design of the study

B) acquisition of data

C) analysis and interpretation of data

D) manuscript preparation

E) obtaining funding

\section{Ejgil Jespersen}

Józef Pitsudski University of Physical Education in Warsaw, Department of Health Science in Biala Podlaska, Poland

ABSTRACT

When reading the masterpiece about "The Agon Motif" by John W. Loy and W. Robert Morford (2019), I was struck by their recurrent reference to the pursuit of honor in agonal sport contests, as it has become common sense to replace honor with dignity in modernity. I take the German social-philosopher Axel Honneth (1995) as a prime example of spelling out the replacement of honor with dignity in what he names "the struggle for recognition". In a historical perspective, however, it looks like, that dignity can be understood as a distribution of honor rather than as an oppositional concept of honor. Recognition should not only be conceptualized at the categorical level, but also understood in terms of 'comparative recognition', which sorts members of a group into an intra-group hierarchy based on their relative merits and, thereby, pave the way for self-esteem (Mark, 2014). Furthermore, Honneth (2008) develops his concept of recognition to a two-level one by including a primordial recognition in terms of mimesis based upon his former concept of basic self-confidence. It is a kind of elementary responsiveness, which always and necessarily contains an element of involuntary openness or devotedness in the bodily-affective sphere. Therefore, I suggest taking mimesis as the precondition of honor into account and understanding dignity as a distribution of honor in the institution of modern sport.

\section{KEYWORDS} sport, honor, dignity, recognition, mimesis

When reading the masterpiece about the Agon motifs by John W. Loy and W. Robert Morford (2019), I was struck by their recurrent reference to the pursuit of honor in agonal sport contests. They write - under the headline: "First among equals" (lat. "primus inter pares") - that

"the pursuit of honor and desire for peer respect is closely connected to the quest for excellence and the desire for distinction and both sets of pursuits and desires serve as primary sources of motivation in agonal systems" (Loy \& Morford, 2019, p. 23).

Here they look at the pursuit of honor at the athlete group-level among peers as equals within a given sport, but, then, when associating status-honor motivation also with a desire for immortality, they leave the peer-group level in favor of a spectator and media mediated perspective:

"We honor exceptional memorable athletes by making them our folk-heroes; and we give them immortality by casting their statues in bronze, enshrining them in sporting halls of fame, or paying homage by retiring their playing uniform or jersey number" (Loy \& Morford, 2019, p. 25) 
In what follows, I wonder how it may be possible to somehow maintain a vestige of ancient agon in terms of the pursuit of honor in modern sport, whilst dignity has replaced honor as the ground on which an individual's legal status rests in modernity? I take the German social-philosopher Axel Honneth (1995) as a prime example of spelling out the replacement of honor with dignity in what he names "the struggle for recognition".

In a historical perspective, however, it looks like, that dignity can be understood as a distribution of honor rather than as an oppositional concept of self-respect. It must be acknowledged, that recognition should not only be conceptualized at the categorical level, as Honneth is doing in the starting point. Recognition should also be understood in terms of "comparative recognition", which sorts members of a group into an intra-group hierarchy based on their relative merits and, thereby, pave the way for self-esteem (Mark, 2014). That is, honor is both spread and differentiated in modern society.

Furthermore, Honneth (2008) develops his concept of recognition to a two-level one by including a primordial recognition in terms of mimesis and based upon his former concept of basic self-confidence in terms of love and friendship. It is a kind of elementary responsiveness, which always and necessarily contains an element of involuntary openness or devotedness in the bodily-affective sphere.

Therefore, I suggest taking mimesis as the precondition of honor into account besides understanding dignity as a distribution of honor in the institution of modern sport.

\section{From honor to dignity}

According to prominent social theorists like Peter L. Berger, Charles Taylor and Axel Honneth, there is an undisputed transition from honor to dignity: Positional honor of aristocratic origin has been replaced by equal dignity in modernity. Taylor (1992, p. 27), for example, distinguishes between two changes that together have made the modern preoccupation with identity and recognition inevitable:

"The first is the collapse of social hierarchies, which used to be the basis for honor. I am using honor in the ancien régime sense in which it is intrinsically linked to inequalities. For some to have honor in this sense, it is essential that not everyone has it. This is the sense in which Montesquieu uses it in his description of monarchy. Honor is intrinsically a matter of 'préférences'.

As against this notion of honor, we have the modern notion of dignity, now used in a universalist and egalitarian sense, where we talk of the inherent 'dignity of human beings', or of citizen dignity. The underlying premise here is that everyone shares in it. It is obvious that this concept of dignity is the only one compatible with a democratic society, and that it was inevitable that the old concept of honor was superseded."

Likewise, Honneth (1995, p. 115) speaks of the universalization of "honor" into "dignity", developing the point in terms of legal recognition. Formerly based on one's rank or standing, legal recognition is now premised on the assumption of the moral autonomy of all humans, and is therefore governed by a norm of equality:

"With the uncoupling of individual rights-claims from the ascription of social status, a general principle of equality emerges for the first time, which henceforth requires of every legal order that it allow no exceptions and privileges".

However, when going back to key figures in the wake of modernity, the way from honor to dignity was not that simple, and we need to question the one-way traffic model of honor and dignity - at the least in case of dueling.

\section{Points of honor in dueling}

The conditions for the good life and human flourishing were object for keen studies in the period of transition to modernity. Some like Rousseau were looking back to a state of nature, when criticizing the current process 
of socialization in which the competitive way of relating to others and the struggle for esteem in the public sphere reduces humans to "specters and phantoms" (Rousseau, [1762] 1968, p. 17).

Others were in opposition to Rousseau's retrospective approach and argued instead prospectively like Hegel, whose focus was to realize true human characteristics in the end state of historical progress. But common to the two camps was a critique of the prevailing concept of honor of aristocratic origin as, for example, practiced in dueling on life and death.

Dueling was one of the most important practices for the maintenance of aristocratic honor, at the moments of transition to modernity, primarily in the eighteenth and nineteenth centuries in Europe as well as in USA and elsewhere (Kiernan, 1988; Holland, 2003). According to LaVaque-Manty (2009, pp. 54-55) dueling over "points of honor" has several key features:

1. Dueling is a form of proof - like "trial by combat", the earliest Western precursor to dueling

2. Points of honor are personal matters, even if they involve collectives like the kin or estate

3. Dueling is necessarily extralegal

4. Dueling is highly ritualized

Rousseau noticed sarcastically how potential duelers were considering the various risks before engaging in a duel: "In this age of enlightenment, everyone knows how to calculate to the penny the worth of his honor and his life", but he also noticed a "shocking opposition" between the incentives of honor and law (cited in LaVaqueManty, 2009, pp. 66, 72).

The emerging civil society with a space for extralegal politics seems in the case of honor to become a power factor alongside of the new state formation and the market. It became strikingly clear, that the struggle for the state's monopoly over violence and the outlawing of dueling was not an easy matter.

Kant, the enlightenment philosopher par excellence, went beyond the opposition of honor and law and tried to connect his abstract rhetoric of equal dignity with the worship of honor in the current public opinion.

In 1794, the new "Civil Code of the Prussian States" specified that a dueler who killed his opponent would be tried for murder or manslaughter and sentenced to death if convicted. Kant was a critic of this statute on behalf of the points of honor.

According to Kant the death penalty must be imposed for the wrongful killing of another, but there are two exceptional cases:

"There are (...) two crimes of death, with regard to which it still remains doubtful whether legislation is also authorized to impose the death penalty" (Kant, [1797] 1996, 6, pp. 335-6).

These two crimes are 1) a mother's killing her child born out of wedlock and 2) an insulted officer's killing the insulting fellow officer in a duel. Kant thinks that killing in these two cases cannot be punished by the highest authority with the death penalty, and that killing of the child and of the fellow officer cannot even be called murder ("homicidium dolosum"). The reason is that the act occurred reluctantly.

The reluctantly committed act ("action invita"), a concept that comes from Aristotle's "operatio mixta" (mixed action), is not fully imputed and puts us somehow in an inter-world between a state of nature and freedom. Achenwall states:

"A reluctantly committed act is an act, whose opposite the actor would prefer if he did not fear that a [great] evil would arise from the alternative act" (cit. in Byrd \& Hrutschka, 2010, p. 230).

That means, that an act of killing in our two special cases is neither murder nor manslaughter, neither an action on the personal level nor a happening at the level of things. Kant suggests that the mother and the officer are left in a state of nature, entitled to do what they must, because of the law's inability to protect what is at stake for the agents - namely honor, and because the demands of honor to what they are subject compete with the 
demands of law - in repeating Rousseau's observation of a "shocking opposition" between the incentives of honor and law. The problem is:

"Legislation cannot remove the disgrace of an illegitimate birth any more than it can wipe away the stain of suspicion of cowardice from a subordinate officer who fails to respond to a humiliating affront with a force of his own rising above fear of death" (Kant, [1797] 1996, 6, p. 336).

The legally protected interests in conflict are the victim's life and the actor's honor, whereby Kant acknowledge - provisionally - the concept of honor prevailing at his time. But Kant also calls for a change in public opinion, which would make special treatment of these cases obsolete.

Thus, Kant is, rather, considered a key figure in a modern transition from social and political systems based on honor to those based on dignity, where "honor" is understood as a hierarchical measure of social value, and "dignity" is understood as the inherent and equal worth of every individual.

Kantian dignity is also traditionally characterized in terms of "autonomy", that is, the idea to treat people as autonomous individuals able to choose their destiny.

However, it is worth remembering, that the concept of dignity should not only be conceptualized in the "usual" Kantian sense as a principle of law, but also as Kant himself acknowledged as a principle of morality establishing a much closer relationship among honor and dignity than is commonly assumed.

Waldron $(2009$, p. 22) stresses even that dignity has always denoted rank by referring to the "Oxford English Dictionary" giving as its second meaning for the term "dignity" as "honorable or high estate, position, or estimation; honor; degree of estimation, rank" and its third "an honorable office, rank, or title; a high official or titular position."

In addition, the relationship in dueling presupposed equality between the duelers and offered opportunities of a noble action of self-defense of one's honor, where death was preferable to disgrace. Becoming "first to survive" in dueling was life-affirming in a very literal sense. But, of course, when violent acts should be kept within rule of law, extra-legal dueling was facing an end in favor of a more peaceful albeit competitive relationship with bodies in struggle for honor, as we know it in modern sport. It is also important to add, that the Kantian concept of honor is a "masculine" one, and that it presupposes that there are women in need of protection (LaVaqueManty, 2009, p. 70).

The social institution of modern sport takes place in civil networks, which in practicing the extra-legal "lex sportive" is not unlike dueling. Therefore, we need to take a closer look at the ethical life in civil society.

\section{Comparative recognition}

The universal respect for the autonomy and dignity of person is only one out of three features of "The Struggle for Recognition", which Honneth (1995) unfolded. Side by side with rights and self-respect he featured basic self-confidence in terms of love and friendship as well as solidarity and self-esteem in civil networks of shared values.

His central focus was (and is) "Gesellschaftskritik", and, therefore, he was originally mostly occupied with legally institutionalized rights to self-respect and "Sittlichkeit", a sort of ethical life involving a sense of what it is that makes one special, unique and particular, and, thereby, fostering self-esteem. Making a difference must, according to Honneth, be something valuable for his or her contribution to the common good:

"To the extent to which every member of a society is in a position to esteem himself or herself, one can speak of a state of societal solidarity" (Honneth, 1995, p. 129).

Thus, the quest for self-esteem in doing something better than others should be associated with solidarity and mutual recognition in a communitarian sense of particularity rather than doing something for one's or its own sake. In other words, one's doings should be community-based in a horizontal manner upholding the value of 
equity and not fall back in pre-modern notions of verticality and hierarchy associated with inegalitarian and estate-based honor.

However, in "The Struggle for Recognition" Honneth is largely dealing with a restricted understanding of mutual recognition encompassing all members of (disadvantaged) communities, since he ignores the fact, that members of a group or community are often sorted into an inter-group hierarchy based on their relative merits - a circumstance labelled "comparative recognition" by Mark (2014, p. 16):

"Because honor is comparative, it puts members of the same group into competition with one another, making recognition conflicts endemic to honor societies".

The shift from archaic honor to modern recognition turns out alternately in this bipartite analysis of recognition and honor. The great equalization should be understood to encompass all members of given communities in society, whereas the competition for comparative recognition, formerly contained within the distinct social strata of hierarchical societies, now likewise, comes to encompass all members of society (Mark, 2014). These parallel processes are making full-fledged recognition for all members of society to a short supply. Comparative recognition is rather reviving honor for the winners as well as the talented and selected few.

We know this problem very well within the world of sport organized in specific sport associations on the global level with their respective ranks of honor based upon orderly performance and individual quest for peer-respect and public reputation. If personal recognition in sport continues to depend on comparisons with others, and honor is a scarce good, then "Sport for All" is in principle not attainable in any sense of honor.

Nevertheless, "Sport for All” is part of Pierre de Coubertin's thoughts of Olympism (Coubertin, 1967, see also Jespersen 1988), and sport as a human right is heralded among the Olympic principles by IOC (2017) as well as by UNESCO (1978). The Olympic ideology is clearly up to modern date of universalism, and sometimes the Olympic Games are even primarily thought as an instrument for the popularization of sports. This line of sport thinking is supported at the political level at least among the wealthy nations around the globe, while they at the same time are struggling for success at the global competitive sport arena.

The question that remains is why the modern norms of individual recognition in sport are frequently not met. Do we have to give up the basic agonal structure of winning and losing in sport? Or should we just be better in facing death, where winning and losing no longer divide, so we - finally - can honor everyone's performative legacy? Good as well as bad people?

\section{Primordial recognition}

Honneth (2008) is, likewise, aware of the problems of inequality and made a renewed effort of diagnosing the ills of society, when he took up an old idea of reification in a new perspective. The term "reification" of social relations in capitalism was coined by Georg Lúkacs in a book on "History and Class Consciousness" published in 1925 and understood as "Verdinglichung" (German), literally "making into a thing".

Honneth (2008) reformulates the concept of reification as "distorted human praxis", where an objectifying attitude is reigning as superior and threatens the primordial affective world-engagement, that is, if cognition is stripped of its sense of "primordial recognition", then we have lost our affective attachment to self, world and others.

With his notion of "primordial recognition" Honneth is coming back to basic self-confidence in love and friendship and expanding this sort of recognition to a general, basic one. Varga (2010) is following this distinction of primordial recognition from usual forms of recognition up by highlighting Honneth's two-level account of recognition. 
In this context there is not space for a thoroughly examination and discussion of primordial recognition as an authentic form of human praxis. I will just focus on one dimension of primordial recognition, namely mimesis, which is particularly relevant for understanding the precondition of honor.

\section{Mimesis as the precondition of honor}

Honneth (2008, p. 17) refers from the onset in his study on "reification" to the founders of the Frankfurt school of social theory and philosophy, Max Horkheimer and Theodor W. Adorno, who in "The Dialectics of Enlightenment" says: "All reification is a forgetting", and to Ludwig Wittgenstein, who in "On Certainty" says: "Knowledge is in the end based on acknowledgment". That means, we should not forget about our predecessors in the history of knowledge as well as our emotional ties with other human beings.

An example from the current research in autism spectrum disorder can lead us on the trail of a possible pathological outcome of a reification of our lives.

One way to approach the growing propagation of autism spectrum disorder is to trace the origin of autistic behavior back to cognitive deficits related to disturbances in the child's abilities to think and speak. This is not Honneth's way of understanding autism (see also He \& Jespersen 2015). He refers instead to other autism researchers, which attribute the decisive cause to the child's lack of receptiveness to the emotional presence of attachment figures. If the child structurally is prevented from emotionally identifying with a concrete second person, then there is a risk for developing an autism spectrum disorder.

"An autistic infant thus isn't 'mentally blind' due to cognitive deficit, but rather because it is in the first instance emotionally blind" (Honneth, 2008, p. 44).

This observation reminds Honneth about Adorno, who traces the rising human mind to an early imitation of a loved figure of attachment.

"Indeed, he states in a well-known aphorism from Minima Moralia that a person doesn't become a person until he or she imitates other persons. Immediately afterward he writes that this kind of imitation constitutes the 'archetype of love"' (Honneth, 2008, p. 44).

Honneth is arguing that if we are forgetting our original connection of our thought to an object of desire $-\mathrm{a}$ beloved person or thing - then we are paving the way for an inhuman and cruel "reification", where other persons are only becoming perceived as physical objects.

The mimetic faculty became gradually repressed in human history through the subject's domination over nature itself. Therefore, the subject's domination of otherness may only be avoided, if we reinstall a mimetic relation in our way of thinking.

The ability to take the perspective of the other is crucial for our way of living and striving together also in the world of sport. If we are becoming exclusively oriented towards the sweetness of victory because of the honor it implies, then sheer power is coming to the fore at the expense of not only playing the game, but also and more importantly of the primordial recognition and admiration of a beloved and honorable role model.

We may in the course of our practices be so extremely focused on winning that we forget paying attention to other motives and aims, which originally moved us to take up a sport. Imitation and identification processes in sport and elsewhere are taking place on an affective level from body to body, which underlie all cognitive and practical activities. While imitation involves specific and obvious aspects of the behavior of the model, identification means that the apprentice comes not only to act but also to feel and think as if he was the model. Thus, identification is not restricted to obvious behavior, but includes the attitudes, tastes, intentions etc. of the model (Jespersen, 1993).

It is a sympathetic understanding, where the act of taking another's perspective requires an antecedent form of recognition that according to Honneth (2008, pp. 45, 152) 
"cannot be grasped in purely cognitive or epistemic concepts, as it always and necessarily contains an element of involuntary openness, devotedness, or love. (...)

Normatively substantial forms of recognition such as are embodied in social institutions of traditional honor, modern love, or equal law, represent (...) various manners in which the existential scheme gets 'filled out' historically."

Thereby an institutional order is stabilized and maintained, which is somehow out of date with a fluid knowledge society. Sport is, thereby, possibly serving as an institutional alternative to disruptions in modernity. The question is if identity is linked to institutional roles or not. In his renowned article "On the obsolescence of the concept of honor", Berger (1970, p. 343) is stressing, that modern consciousness, in its conception of the self, tends toward a curious a-historicity.

"In a world of honor, identity is firmly linked to the past through the reiterated performance of prototypical acts. In a world of dignity, history is the succession of mystifications from which the individual must free himself to attain 'authenticity"'.

When emphasizing the affective, non-epistemic and pre-cognitive character of our attachments to loved figures and the associated existential significance in the world of sport and elsewhere, we should, of course, be aware of the non-normative character of this relation to the world as a whole. We are primarily dealing with "background practices" (Dreyfus, 2017), which lie prior to the subject-object dichotomy and outside normative considerations.

If we want to exercise a counterweight to the widespread cognitive-instrumental way of seeing the world and counteract the reification of social relations and the world's phenomena at large, then we must, however, take these background practices into account as the ground of morality. Thus, Honneth is stressing, that it is only when our reflexive thoughts lose consciousness of their origin in emotional ties and the mimetic faculty, that a polar opposition of conceptual thought and empathetic engagement is construed and, thereby, paving the way of a reigning and pathologizing reification.

That is why we should not only avoid a crude distinction between honor and dignity in modernity but also be aware of the precondition of honor in mimesis in the institution of modern sport.

\section{REFERENCES}

Berger, P. (1970). On the Obsolescence of the Concept of Honour. European Journal of Sociology, 11, 339-47.

Byrd, B.S., \& Hrutschka, J. (2010). Kant's Doctrine of Right. A Commentary. Cambridge, UK: Cambridge University Press.

Coubertin, P. de (1967). The Olympic Idea: Discourses and Essays. Schorndorf near Stuttgart: Verlag Karl Hofman.

Dreyfus, H.L. (2017). Background Practices. Essays on the Understanding of Being. Edited by M. A. Wrathall. Oxford, UK: Oxford University Press.

He, J., \& Jespersen, E. (2015). The Embodied Nature of Autistic Learning: Implications for Physical Education. Physical Culture and Sport. Studies and Research, LXV, 63-73.

Holland, B. (2003). Gentlemen's Blood. A History of Dueling. New York, NY: Bloomsbury.

Honneth, A. (1995). The Struggle for Recognition. The Moral Grammar of Social Conflicts. Cambridge, MA: Polity Press. Honneth, A. (2008). Reification. A New Look at an Old Idea. With Butler, J., Geuss, R. \& Lear, J. Edited by M. Jay. New York, NY: Oxford University Press.

IOC (2017). Olympic Charter - in force as from 15 September 2017. Lausanne: International Olympic Committee.

Jespersen, E. (1988). Sport, frihed og lighed. Pierre de Coubertin og olympismen /Sport, freedom and equality. Pierre de Coubertin and Olympism/. Idrcetshistorisk Arbog. 4, 25-37.

Jespersen, E. (1993). Fra krop til krop. Gensyn med idrætsmesterlæren /From body to body. Revisiting apprenticeship in sport/. Dansk Pcedagogisk Tidsskrift 41(1), 26-30. 
Kant, I. ([1797] 1996). The Metaphysics of Moral. Trans. and ed. by M. Gregor. New York, NY: Cambridge University Press.

Kiernan, V. (1988). The Duel in European History. Honour and the Reign of Aristocracy. Oxford University Press.

LaVaque-Manty, M. (2009). The Playing Fields of Eton. Equality and Excellence in Modern Meritocracy. Ann Arbor, MI: The University of Michigan Press.

Loy, J.W., \& Morford, R. (2019). The Agon Motifs: Redux. A Study of the Contest Element in Sport. Physical Culture and Sport. Studies and Research, 82, 10-45.

Mark, D.C. (2014). Recognition and Honor: A Critique of Axel Honneth's and Charles Taylor's Histories of Recognition. Constellations, 21(1), 16-31.

Rousseau, J.-J. ([1762] 1958). The Social Contract. Baltimore, MD: Penguin Books.

Taylor, C. (1994). The Politics of Recognition. In A. Gutmann (Ed.), Multiculturalism: Examining the Politics of Recognition (pp. 25-73). Princeton, NJ: Princeton University Press.

UNESCO (1978). International Charter of Physical Education and Sport. Paris: UNESCO.

Varga, S. (2010). Critical Theory and the Two-Level Account of Recognition - Towards a New Foundation? Critical Horizons, 11(1), 19-33.

Waldron, J.J. (2009). Dignity, Rank, and Rights: The 2009 Tanner Lectures at UC Berkeley. New York, NY: New York School of Law.

\section{AUTHOR'S ADDRESS:}

Ejgil Jespersen, Prof.

Józef Piłsudski University of Physical Education in Warsaw, branch in Biała Podlaska

Akademicka 2

21-500 Biała Podlaska

Poland

E-mail: e.jespersen@awf-bp.edu.pl

Received: 9 March 2019; Accepted: 11 April 2019 